\title{
ANALISIS PLASTIS JEMBATAN BOX GIRDER DENGAN PENAMPANG SINGLE BOX
}

\author{
Yuslinda \\ Teknik Sipil, Fakultas Teknik, Universitas Sains Cut Nyak Dhien-Langsa, 24416, Aceh \\ email:yuslinda.civil@yahoo.co.id
}

DOI: : http://dx.doi.org/10.29103/tj.v11i1.349

(Received: August 2020 / Revised: December 2020 / Accepted: January 2021)

\begin{abstract}
Abstrak
Tujuan penelitian ini untuk menganalisis perilaku plastis penampang single box girder dengan model bilinier dan strain hardening. Hal-hal yang dipelajari adalah hubungan momen-kelengkungan, momen plastis, panjang daerah inelastis dan faktor bentuk (shape factor). Jembatan yang dianalisis mempunyai panjang bentang 40 meter dan lebar 10 meter. Perencanaan penampang jembatan dilakukan dengan menggunakan bantuan program SAP 2000 versi 15, dengan mengikuti prosedur yang ditetapkan dalam RSNI T-03-2005. Beban yang diperhitungkan adalah beban mati dan beban hidup saja dan didasarkan pada RSNI T-02-2005. Analisis dengan model bilinier, momen plastis (Mp) didapatkan sebesar $160 \mathrm{kNm}$. Untuk analisis dengan model strain hardening, momen plastis (Mps) sebesar $214 \mathrm{kNm}$. Kenaikan momen plastis akibat diperhitungkan strain hardening penampang single box, yaitu sebesar 25,3\%. Kenaikan daerah inelastis akibat diperhitungkan strain hardening menjadi sekitar 4 kali daerah inelastis bila strain hardening tidak diperhitungkan. Akhirnya, dalam tulisan ini diperbandingkan hubungan momen-kelengkungan penampang single box baik menggunakan model bilinier maupun menggunakan model dengan strain hardening.
\end{abstract}

Kata kunci: Single box, perilaku plastis, strain hardening, momen plastis, hubungan momen-kelengkungan

\begin{abstract}
The purpose of this study was to analyze the plastic behavior of a single box girder cross section with a linear and strain hardening model. The things learned are the relationship of moment-curvature, plastic moment, length of inelastic region and form factor (shape factor). The bridge analyzed has a span length of 40 meters and a width of 10 meters. Bridge cross section planning is done using the help of the SAP 2000 program version 15, following the procedures set out in RSNI T-03-2005. Expenses calculated are dead load and live load only and are based on RSNI T-022005. Analysis with a linear model, the plastic moment (Mp) obtained for $160 \mathrm{kNm}$. For analysis with the strain hardening model, the plastic moment (Mps) is $214 \mathrm{kNm}$. The increase in plastic moment due to calculated single-section cross-section hardening strains is equal to $25.3 \%$. The increase in inelastic area due to hardening strain is calculated to be around 4 times the inelastic area if the hardening strain is not taken into account. Finally, in this paper the single-box cross-section crosssection relationship is compared, both using a linear model or using a strain hardening model.
\end{abstract}

Keywords: Single box, plastic behavior, strain hardening, plastic moment, relationship of moment-curvature 


\section{Latar Belakang}

Jembatan box girder mempunyai beberapa bentuk penampang, yaitu single box, twin box, multiple box, dan cellular box (Brockenbrought, 1999). Bentuk penampang tersebut mempengaruhi perilaku plastis sebuah gelagar walaupun gelagar tersebut didesain mempunyai momen leleh yang sama.

Hubungan tegangan-regangan baja pada saat awal pembebanan adalah linier sampai tercapainya tegangan leleh, diikuti dengan penambahan regangan tanpa terjadinya penambahan tegangan sampai suatu nilai regangan tertentu, untuk selanjutnya terjadi strain hardening (penambahan tegangan yang diikuti dengan penambahan regangan) sampai tercapainya tegangan maksimum. Bila terus diberi beban tegangan akan menurun sampai baja putus pada suatu nilai regangan tertentu (Brockenbrought, 1999; Setiawan, 2008; Wong, 2009). Dalam analisis dan desain, daerah strain hardening tersebut tidak diperhitungkan. Model hubungan tegangan-regangan diidealisasikan berbentuk bilinier, yaitu dari titik asal sampai titik leleh dengan kemiringan garis sebesar modulus elastisitas baja; diteruskan garis lurus dalam arah mendatar dengan tegangan konstan sebesar tegangan leleh sampai baja putus (Badan Standarisasi Nasional, 2005; Setiawan, 2008; Wong, 2009).

Tujuan penelitian ini adalah untuk melihat kontribusi dari strain hardening terhadap perilaku platis gelagar jembatan box girder bentuk penampang single box sampai beban runtuh. Hal-hal yang dipelajari adalah besarnya momen plastis, panjang daerah inelastis, faktor bentuk (shape factor) dan hubungan momenkelengkungan. Untuk tercapainya tujuan tersebut maka dalam kajian ini telah direncanakan gelagar box girder yaitu single box. Selanjutnya dilakukan analisis penampang dengan dan tanpa memperhitungkan strain hardening pada hubungan tegangan-regangannya.

Perencanaan gelagar jembatan dilakukan dengan menggunakan bantuan program SAP2000 versi 15 dengan mengikuti prosedur yang ditetapkan dalam RSNI T-03-2005. Beban yang diperhitungkan adalah beban mati dan beban hidup saja dan didasarkan pada RSNI T-02-2005. Deformasi pada sebuah gelagar jembatan box girder terdiri atas deformasi akibat lentur dan deformasi akibat geser. Dalam penelitian ini, analisis dibatasi pada deformasi akibat lentur saja, sedangkan pengaruh dari deformasi geser tidak diperhitungkan.

\section{Metode Penelitian}

Penelitian perilaku plastis gelagar jembatan box girder baja ini dilakukan dengan terlebih dahulu mendesain penampang single box. Desain penampang dilakukan dengan bantuan program SAP 2000 v. 15 dan didasarkan pada RSNI T03-2005. Beban yang diperhitungkan untuk desain penampang hanyalah beban mati dan beban hidup dan dihitung berdasarkan RSNI T-02-2005.

Panjang jembatan ditetapkan $40 \mathrm{~m}$ dengan lebar lantai kendaraan $8 \mathrm{~m}$ ditambah trotoar pada sisi kiri dan kanan masing-masing selebar 1 meter. Jadi lebar total 10 meter.

Baja yang digunakan adalah baja mutu BJ 55 berdasarkan RSNI T-02-2005 dengan data-data sebagai berikut: 
- Tegangan leleh $\left(f_{y}\right)=410 \mathrm{MPa}$

- Regangan leleh $\left(\varepsilon_{y}\right)=0,00205$

- Modulus elastisitas $(E)=200.000 \mathrm{MPa}$

- Angka Poison $(v)=0,3$

- Tegangan putus $\left(f_{s u}\right)=550 \mathrm{MPa}$

- Regangan putus $\left(\varepsilon_{s u}\right)=0,13$

- Regangan pada saat terjadi strain hardening $\left(\varepsilon_{\text {sh }}\right)=0,02$

- Modulus strain hardening $\left(E_{s h}\right)=10.000 \mathrm{MPa}$.

Ukuran Penampang Single Box Girder Baja dari hasil perencanaan didapat ukuran penampang single box girder baja seperti pada Gambar 1.

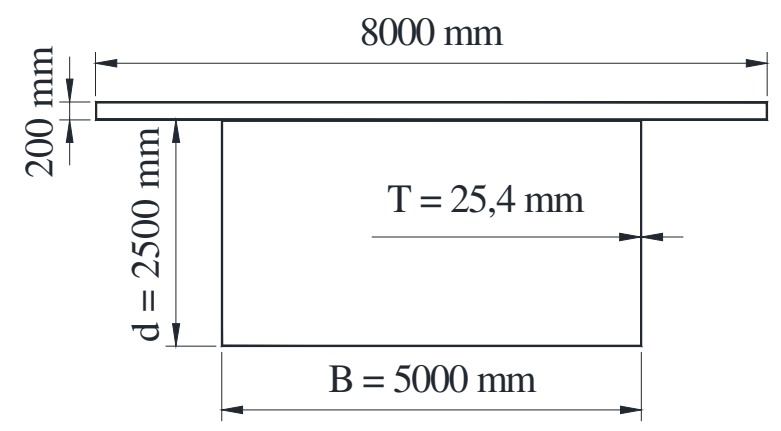

Gambar 1 Penampang Single box girder

Hasil pengecekan keamanan penampang pada batas beban ultimit dan batas beban layan seperti dipersyaratkan oleh RSNI T-02-2005 diperlihatkan pada Tabel 1.

Tabel 1 Perbandingan momen dan geser pada batas ultimit serta tegangan dan lendutan pada batas layan

\begin{tabular}{|c|c|c|}
\hline Tipe Penampang box girder & & Single box \\
\hline \multirow[t]{2}{*}{ Faktor Beban batas ultimit } & $M u / \square M n$ & 0,739 \\
\hline & $V u / \square V n$ & 0,215 \\
\hline \multirow[t]{3}{*}{ Faktor Beban Batas beban layan } & $\sigma / \bar{\sigma}$ & 0,794 \\
\hline & $\delta / \bar{\delta}$ & 0,798 \\
\hline & $\tau / \bar{\tau}$ & 0,215 \\
\hline Momen leleh & $M y$ & 147947 \\
\hline
\end{tabular}

Jembatan box girder adalah sebuah jembatan dimana struktur atas jembatan terdiri dari balok-balok penopang utama yang berbentuk kotak berongga. Box girder baja umumnya berpenampang kotak atau trapesium yang berbentuk terbuka atau tertutup.

\subsection{Konsep Perencanaan Jembatan Berdasarkan RSNI T-03-2005}

Perencanaan secara PBKT atau Metode Load and Resistance Factored Design (LRFD) dilakukan untuk mengantisipasi suatu kondisi batas ultimit, yang terjadi antara lain: 
a. Terjadi keruntuhan lokal pada satu atau sebagian komponen struktur jembatan.

b. Kehilangan keseimbangan statis akibat keruntuhan atau kegagalan pada sebagian komponen struktur atau keseluruhan struktur jembatan.

c. Keadaan purna-elastis atau purna-tekuk di mana satu bagian komponen jembatan atau lebih mencapai kondisi runtuh.

d. Kerusakan akibat kelelahan dan/atau korosi sehingga terjadi kehancuran.

e. Kegagalan dari pondasi yang menyebabkan pergeseran yang berlebihan atau keruntuhan bagian utama dari jembatan.

Pendekatan umum berdasarkan faktor daya tahan dan beban, atau disebut dengan Load and Resistance Factored Design (LRFD) ini adalah hasil penelitian dari Advisory Task Force yang dipimpin oleh Galambos (1978). Dalam perencanaan dengan LRFD dipersyaratkan

$$
Q_{u} \leq \phi R_{n}
$$

di mana:

$$
\begin{aligned}
& Q_{u}=\text { beban berfaktor, } \\
& \phi=\text { faktor reduksi kekuatan, dan } \\
& R_{n}=\text { kekuatan nominal. }
\end{aligned}
$$

Perencanaan berdasarkan batas layan (PBL) atau Metode Allowable Stress Design (ASD), dilakukan untuk mengantisipasi suatu kondisi batas layan, antara lain:

a. Tegangan kerja dari suatu komponen struktur jembatan, yang melampaui nilai tegangan yang diijinkan, sehingga berpotensi mengakibatkan kelelehan pada komponen baja.

b. Deformasi permanen dari komponen struktur jembatan, yang melampaui nilai deformasi ijinnya, Besarnya lendutan biasanya juga diperiksa pada kondisi beban kerja dan tidak boleh melebihi 1/800 panjang bentang jembatan.

c. Vibrasi yang terjadi sehingga menimbulkan instabilitas atau kekhawatiran struktural lainnya terhadap keamanan jembatan pada kondisi layan.

d. Bahaya permanen termasuk korosi dan kelelahan yang mengurangi kekuatan struktur dan umur layan jembatan.

e. Bahaya banjir di daerah sekitar jembatan.

\subsection{Hubungan Tegangan-Regangan Baja}

Hubungan tegangan-regangan baja dengan Model Bilinier dapat dijelaskan oleh Wong (2009) menyatakan untuk analisis elastis-plastis, model baja yang digunakan berupa kurva hubungan tegangan-regangan bilinier berupa dua garis lurus dan dapat dinyatakan sebagai persamaan:

$$
\begin{array}{lll}
f_{s}=E_{s} \varepsilon_{s} & \text { untuk } & \varepsilon_{s} \leq \varepsilon_{y} \\
f_{s}=f_{y} & \text { untuk } & \varepsilon s>\varepsilon_{y}
\end{array}
$$

di mana $f_{s}$ adalah tegangan baja, $E_{s}$ adalah modulus elastisitas baja, $\varepsilon_{s}$ adalah regangan baja, $\varepsilon_{y}$ adalah regangan leleh baja, dan $f_{y}$ adalah tegangan leleh. 
Sementara model dengan Strain Hardening dijelaskan oleh Thompson and Park (1978) menyatakan strain hardening (pengerasan regangan) adalah penguatan baja untuk deformasi plastis (perubahan bentuk secara permanen atau tidak dapat kembali seperti semula).

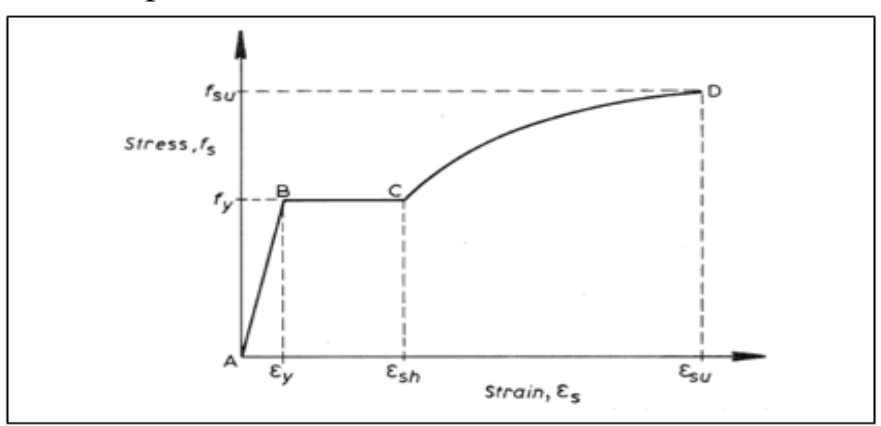

Gambar 2 Hubungan tegangan-regangan dengan strain hardening

Sumber: Thompson dan Park, (1978)

Hubungan tegangan-regangan dibedakan atas 3 daerah, yaitu daerah $\mathrm{AB}$, BC dan CD seperti diperlihatkan pada Gambar 2.

Daerah $\mathrm{AB}: \varepsilon_{s} \leq \varepsilon_{y}$

$$
f_{s}=E_{s} \varepsilon_{s}
$$

Daerah BC: $\varepsilon_{y} \leq \varepsilon_{s} \leq \varepsilon_{s h}$

$$
f_{s}=f_{y}
$$

Daerah CD: $\varepsilon_{s} \geq \varepsilon_{s h}$

$$
f_{s}=f_{y}\left\{\frac{m\left(\varepsilon_{s}-\varepsilon_{s h}\right)+2}{60\left(\varepsilon_{s}-\varepsilon_{s h}\right)+2}+\frac{\left(\varepsilon_{s}-\varepsilon_{s h}\right)(60-m)}{2(30 q+1)^{2}}\right\}
$$

di mana:

$$
m=\frac{\left(\frac{f_{s u}}{f_{y}}\right)(30 q+1)^{2}-60 q-1}{15 q^{2}}
$$

di mana:

$\varepsilon_{s h}=$ regangan pada saat strain hardening dimulai,

$f_{s u}=$ tegangan baja putus, dan

$\varepsilon_{s u}=$ regangan baja putus.

Hasil penelitian oleh Byfield, Davies and Dhanalakshmi (2005) menyimpulkan bahwa perilaku strain hardening baja tidak tergantung kepada ketebalan material dan mutu baja. Hal ini memungkinkan generalisasi dari hubungan tegangan-regangan untuk baja canai panas untuk didefinisikan. Sebuah teknik pemodelan disajikan yang memungkinkan perilaku non linier momendeformasi dari balok diprediksi secara akurat menggunakan data mill test. 


\subsection{Analisis Elastis-Plastis Penampang Bukan Persegi}

Sebelum penampang mengalami leleh, analisis penampang dapat menggunakan metode elastis (Wong, 2009; Wahyudi and Rahim, 1992).

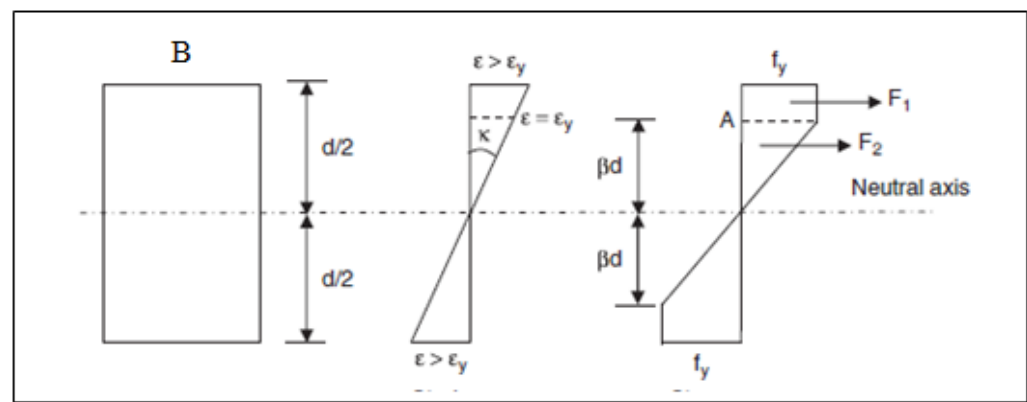

Gambar 3 Perilaku elastis-plastis

Sumber: Wong, (2009)

Setelah sebagian penampang mengalami leleh, maka distribusi regangan dan tegangan sepanjang tinggi penampang diperlihatkan pada Gambar 3 . Kelengkungan pada batas leleh dapat dihitung dengan persamaan:

$$
k=\frac{f_{y}}{E \beta d}
$$

di mana:

$k=$ kelengkungan,

$\mathrm{d}=$ tinggi penampang,

$\beta=$ faktor kedalaman penampang yang sudah leleh

Hubungan momen-kelengkungan untuk penampang bukan persegi dalam kondisi elastis-plastis ini dapat dibentuk dengan langkah-langkah sebagai berikut (Wong, 2009):

1. Bagi penampang atas strip-strip yang kecil dalam arah horizontal

2. Hitung luas penampang setiap strip

3. Tentukan nilai $\beta$ yang menunjukkan daerah yang telah terjadi plastisifikasi. Biasanya nilai $\beta$ dimulai dari 0,5

4. Hitung kelengkungan dengan menggunakan (Pers.7)

5. Hitung regangan setiap strip dengan menggunakan persamaan $\varepsilon=\kappa y$, di mana $y=$ jarak dari pusat strip ke garis netral

6. Hitung tegangan untuk setiap strip menggunakan model hubungan teganganregangan.

7. Hitung gaya aksial setiap strip dengan cara mengalikan tegangan strip dengan luas penampang strip

8. Hitung momen setiap strip dengan cara mengalikan gaya setiap strip dengan jarak strip ke garis netral

9. Jumlahkan momen setiap strip. Ini merupakan kapasitas momen elastis-plastis dari penampang 
10. Set nilai $\beta$ yang lain yang lebih kecil sampai nilai $\beta=0$ dan ulangi langkahlangkah 4-9 untuk setiap nilai $\beta$. Pada saat nilai $\beta=0$, maka seluruh penampang telah terjadi plastifikasi, dan momen pada keadaan tersebut disebut momen plastis.

\subsection{Hubungan Momen-Kelengkungan}

Untuk menentukan hubungan momen-kelengkungan dilakukan analisis penampang. Analisis penampang terhadap setiap penampang yang direncanakan dilakukan sebanyak dua kali, yaitu 1) dengan menggunakan model hubungan tegangan-regangan bilinier; dan 2) dengan menggunakan model hubungan tegangan-regangan yang memperhitungkan strain hardening.

Metode dan langkah-langkah analisis penampang dengan menggunakan model hubungan tegangan-regangan bilinier dilakukan berdasarkan metode yang diajukan oleh Wong (2009). Dalam hal ini, bagian flens atas dan bawah penampang masing-masing dibagi menjadi 10 strip dan bagian webnya dibagi menjadi 180 strip.

Metode dan langkah-langkah analisis penampang dengan model hubungan tegangan-regangan yang memperhitungkan strain hardening sebagai berikut:

1. Bagi penampang atas strip-strip horizontal. Bagian flens atas dan bawah dibagi menjadi 10 strip dan bagian webnya dibagi menjadi 180 strip.

2. Tentukan nilai regangan pada serat terluar sebesar regangan leleh baja;

3. Hitung regangan rata-rata pada setiap strip;

4. Hitung tegangan rata-rata pada setiap strip dengan menggunakan hubungan tegangan-regangan yang dikemukakan oleh Thompson and Park, (1978).

5. Hitung gaya-gaya dalam pada setiap strip;

6. Hitung besarnya momen akibat gaya-gaya dalam tersebut;

7. Hitung besarnya kelengkungan akibat regangan yang diberikan;

8. Perbesar nilai regangan pada serat terluar dengan tingkat kenaikan tertentu;

9. Ulangi langkah 3 sampai 8;

10. Perhitungan dihentikan apabila penampang sudah mengalami sendi plastis, yaitu regangan di seluruh penampang sudah melewati regangan leleh

11. Tentukan nilai momen plastis;

12. Gambarkan hubungan momen dan kelengkungan.

\subsection{Panjang Daerah Inelastis dan Faktor Bentuk}

Panjang daerah inelastis didapat dengan memplot besarnya momen plastis $\left(M_{p}\right)$ dan momen leleh $\left(M_{y}\right)$ pada diagram momen lentur sepanjang balok. Dalam hal ini panjang daerah inelastis yang dihitung disini adalah bila beban bekerja terpusat di tengah bentang balok. Faktor bentuk didapat dengan mengambil nilai perbandingan antara momen plastis $\left(M_{p}\right)$ dan momen leleh $\left(M_{y}\right)$.

\section{Hasil dan Pembahasan}

\subsection{Momen Plastis, Faktor Bentuk dan Panjang Daerah Inelastis}

Besarnya momen plastis, faktor bentuk, panjang daerah inelastis penampang single box girder baik yang memperhitungkan strain hardening maupun yang tidak memperhitungkan strain hardening seperti diperlihatkan pada Tabel 2 di mana dapat diketahui bahwa untuk analisis tanpa memperhitungkan 
strain hardening, momen plastis single box girder sebesar $(M p)=160 \mathrm{kNm}$ dan untuk analisis dengan memperhitungkan strain hardening $(M p s)=214 \mathrm{kNm}$. Faktor bentuk model bilinier pada penampang single box girder sebesar 1,08 sedangkan model strain hardening sebesar 1,44.

Tabel 2. Besarnya momen plastis, faktor bentuk dan panjang daerah

\begin{tabular}{cccccccccc}
\hline & \multicolumn{2}{c}{ Tanpa strain hardening } & \multicolumn{2}{c}{ Dengan strain hardening } & & & \\
Penampang & $\begin{array}{c}M_{p} \\
(\mathrm{kNm})\end{array}$ & $s$ & $\begin{array}{c}x_{p} \\
(\mathrm{~m})\end{array}$ & $\begin{array}{c}M_{p s} \\
(\mathrm{kNm})\end{array}$ & $s_{s}$ & $\begin{array}{c}x_{p s} \\
(\mathrm{~m})\end{array}$ & $M_{p s} / M_{p}$ & $\boldsymbol{s}_{s} / \boldsymbol{s}$ & $\boldsymbol{x}_{p s} / \boldsymbol{x}_{p}$ \\
\hline Single box & 160069 & 1,08 & 3,026 & 213678 & 1,44 & 12,302 & 1,335 & 1,333 & 4,065 \\
\hline
\end{tabular}

$M_{p}$ adalah momen plastis tanpa strain hardening; $s$ adalah faktor bentuk tanpa strain hardening; $x_{p}$ adalah panjang daerah inelastis tanpa strain hardening; $M_{p s}$ adalah momen plastis dengan strain hardening; $x_{p s}$ adalah panjang daerah inelastis dengan strain hardening; $s_{s}$ adalah faktor bentuk dengan strain hardening.

Jika dibandingkan hasil ini dengan hasil perbandingan momen berfaktor terhadap tahanan momen dalam $\left(M_{u} / \phi M_{n}\right)$, maka terlihat penampang single box mempunyai nilai rasio yang besar. Hal ini menunjukkan bahwa penampang single box aman. Kesesuaian antara hasil analisis penampang dengan tidak memperhitungkan strain hardening dengan hasil analisis kekuatan berdasarkan RSNI T-02-2005 adalah karena dalam perencanaan jembatan dengan RSNI T-032005 hubungan tegangan-regangan baja dianggap bilinier.

Berbeda dengan hasil analisis tanpa memperhitungkan strain hardening, untuk analisis dengan memperhitungkan strain hardening, momen plastis lebih besar dibandingkan tidak memperhitungkan strain hardening. Akibatnya penampang single box mempunyai faktor bentuk yang besar.

Kenaikan momen plastis akibat diperhitungkan strain hardening pada penampang single box, yaitu sebesar $25,3 \%$. Untuk panjang daerah inelastis terjadi kenaikan daerah inelastis akibat diperhitungkan strain hardening menjadi sekitar 4 kali daerah inelastis bila strain hardening tidak diperhitungkan.

Gambar 4, 5, dan 6 memperlihatkan grafik perbandingan nilai momen plastis, panjang daerah inelastis dan faktor bentuk penampang single box girder baik yang memperhitungkan strain hardening maupun yang tidak memperhitungkan strain hardening.

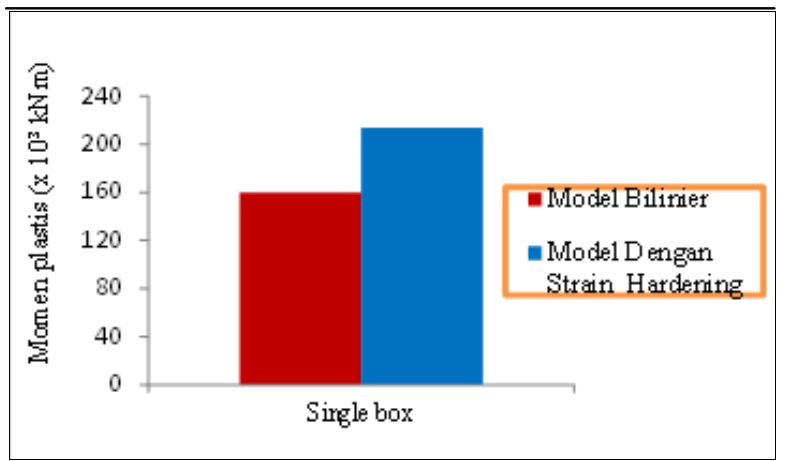

Gambar 4 Grafik perbandingan momen plastis penampang single box 


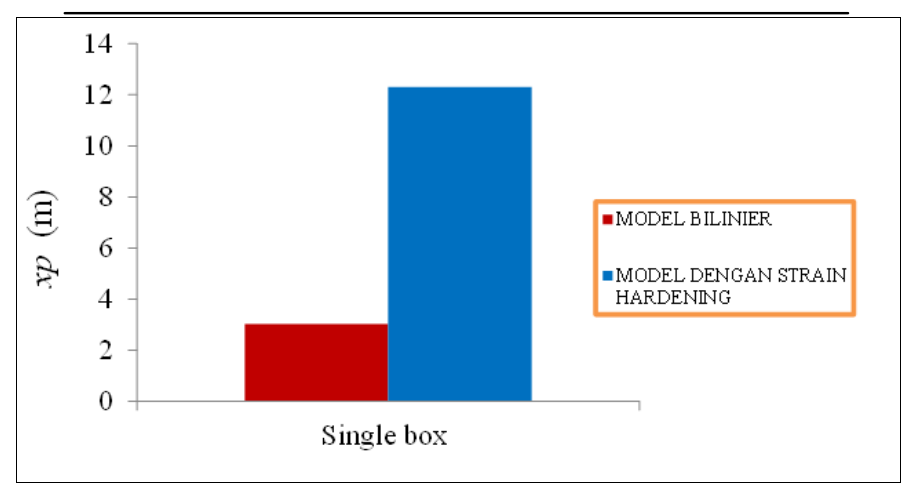

Gambar 5 Grafik perbandingan panjang daerah inelastis penampang single box

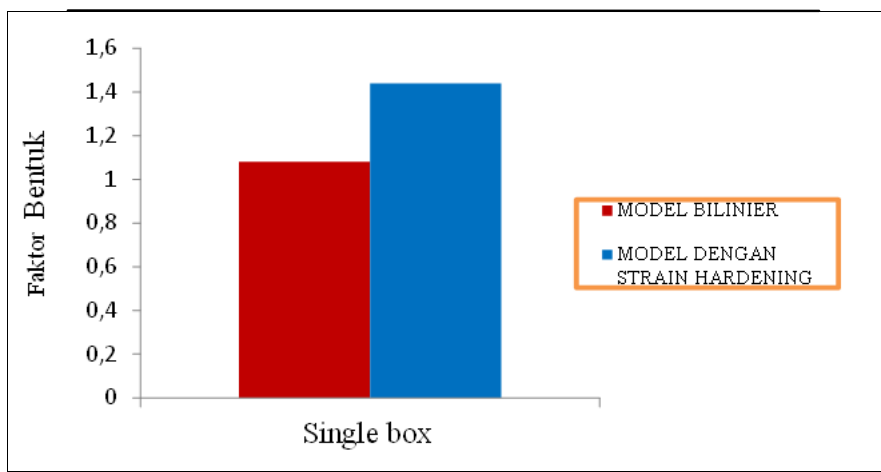

Gambar 6 Grafik perbandingan faktor bentuk penampang single box

\subsection{Hubungan Momen-Kelengkungan}

\subsubsection{Efek bentuk penampang box girder terhadap momen-kelengkungan}

Gambar 7 memperlihatkan perbandingan momen-kelengkungan model bilinier pada penampang single box girder. Hubungan momen-kelengkungan penampang single box girder sampai momen leleh (tercapainya leleh pada serat terluar penampang) adalah linier. Besarnya momen dan kelengkungan pada titik leleh penampang single box girder adalah $147.947 \mathrm{kNm}$ dan 0,0016 /m.

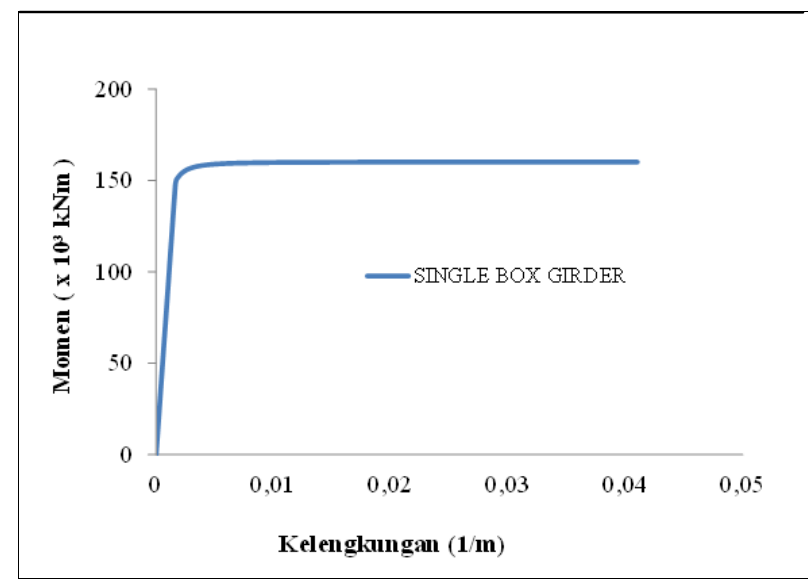

Gambar 7 Grafik momen-kelengkungan penampang single box model bilinier 
Setelah momen leleh, hubungan momen-kelengkungan melengkung non linier sampai suatu nilai momen tertentu (misal titik $\mathrm{X}$ ). Koordinat titik X penampang single box adalah $(0,0046 / \mathrm{m}, 158.681 \mathrm{kNm}$. Nilai penampang single box pada titik $\mathrm{X}$ tersebut adalah 0,18 yang berarti bahwa 0,32 kali tinggi penampang di bagian atas dan bawah sudah mengalami leleh.

Setelah titik $\mathrm{X}$ tersebut, hubungan momen-kelengkungan kembali linier dengan penambahan momen yang sangat kecil sampai seluruh penampang mengalami leleh. Pada saat seluruh penampang mengalami leleh, momen plastis dicapai.

Grafik perbandingan momen kelengkungan model dengan strain hardening untuk penampang single box, twin box, multiple box, dan cellular box ditunjukkan pada Gambar 8.

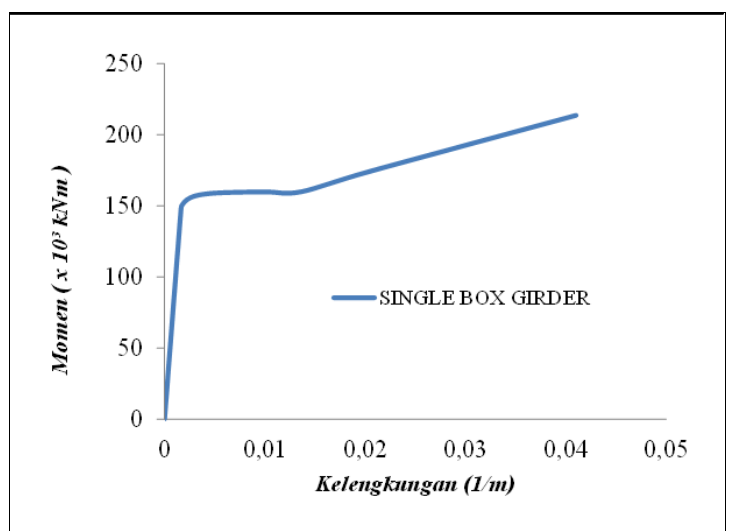

Gambar 8 Grafik momen-kelengkungan penampang single box model dengan strain hardening

Dari gambar tersebut terlihat bahwa setelah nilai kelengkungan tertentu (misal titik Y, terjadi kenaikan momen penampang single box yang sangat signifikan.

\subsubsection{Efek strain hardening terhadap momen-kelengkungan}

Grafik perbandingan hubungan momen-kelengkungan antara model bilinier dengan model strain hardening untuk penampang box girder diperlihatkan pada Gambar 9 Seperti telah dijelaskan sebelumnya dan seperti terlihat pada gambar tersebut, bahwa setelah nilai kelengkungan tertentu (misal titik Y) terjadi kenaikan momen yang sangat signifikan sampai tercapainya leleh pada penampang single box girder (momen plastis tercapai). Hal ini menunjukkan bahwa mulai titik $\mathrm{Y}$ tersebut sebagian penampang sudah mengalami strain hardening.

Untuk penampang single box, koordinat titik Y adalah $(0,0137 / \mathrm{m}, 159.930$ $\mathrm{kNm}$ ). Besarnya nilai pada saat ini adalah 0,06 yang berarti 0,44 kali tinggi penampang di bagian atas dan bawah sudah mengalami leleh. Besarnya nilai pada saat ini adalah juga 0,07 yang berarti 0,43 kali tinggi penampang di bagian atas dan bawah sudah mengalami leleh. Terlihat bahwa efek strain hardening dimulai pada nilai kelengkungan yaitu pada kelengkungan $0,0137 / \mathrm{m}$. 


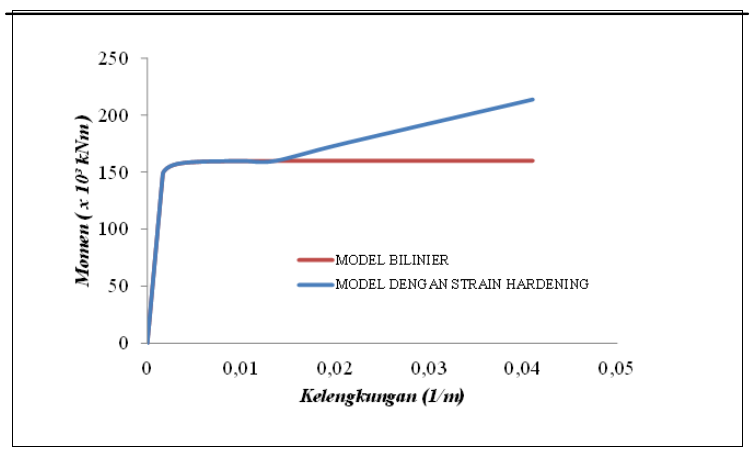

Gambar 9 Grafik perbandingan momen-kelengkungan antara model bilinier dengan strain hardening single box

Setelah titik Y, penambahan momen dengan model bilinear tidak lagi signifikan sampai tercapai Mp (keseluruhan penampang mengalami leleh sedangkan untuk model dengan strain hardening penambahan momennya sangat signifikan sampai tercapai Mp. Dengan Mp model yang memperhitungkan Srain hardening untuk penampang single box sebesar $213.678 \mathrm{kNm}$

\section{Kesimpulan dan Saran}

Untuk analisis model bilinier, $M_{p}$ sebesar $160.069 \mathrm{kNm}$ dan $M_{y}$ sebesar $147.947 \mathrm{kNm}$, Hal ini sesuai dengan perhitungan kekuatan penampang berdasarkan RSNI T-03-2005 penampang single box mempunyai nilai $M_{u} / \phi M_{n}$ yang aman. Untuk analisis memperhitungkan strain hardening, $M_{p}$ single box sebesar $213.678 \mathrm{kNm}$. Dengan demikian besarnya kenaikan $M_{p}$ akibat diperhitungkan strain hardening yaitu sebesar 25,3\%. Kenaikan panjang daerah inelastis $\left(x_{p}\right)$ terjadi secara signifikan akibat diperhitungkan strain hardening, dimana $x_{p}$ menjadi sekitar 4 kali daerah inelastis bila strain hardening tidak diperhitungkan.

Untuk analisis model bilinier hubungan momen-kelengkungan kembali linier dengan penambahan momen yang sangat kecil sampai keseluruhan penampang leleh (tercapainya $M_{p}$ ). Untuk analisis dengan strain hardening, setelah kelengkungan mencapai nilai $0,0137 / \mathrm{m}, M_{p}$ kembali meningkat secara signifikan untuk penambahan kelengkungan selanjutnya sampai tercapai $M_{p}$.

\section{Daftar Kepustakaan}

Brockenbrought, R. L. (1999) Structural Steel Designer's Handbook 3rd edition. New York: McGraw-Hill.

BSN (Badan Standarisasi Nasional) (2005) RSNI T-03-2005 Perencanaan Struktur Baja Untuk Jembatan, Bandung: Badan Standardisasi Indonesia.

Byfield, M. P., Davies, J. M. and Dhanalakshmi, M. (2005) 'Calculation of the strain hardening behaviour of steel structures based on mill tests', Journal of Constructional Steel Research, 61(2). doi: 10.1016/j.jcsr.2004.08.001. 
Galambos, T. V (1978) 'Load Factor Design of Steel Buildings', AISC Engineering Journal.

RSNI T-02-2005Badan Standardisasi Nasional (2005) Pembebanan Untuk Jembatan.

Setiawan, A. (2008) Perencanaan Struktur Baja Dengan Metode LRFD (Berdasarkan SNI 03-1729- 2002). Jakarta: Erlangga.

Thompson, K. J. and Park, R. (1978) Stress-strain model for grade 275 reinforcing steel with cyclic loading., Bull. New Zealand Nat. Soc. for Earthquake Engrg., Waikanae, New Zealand.

Wahyudi, L. and Rahim, S. (1992) Metode Plastis, Analisis dan Desain. Jakarta: Gramedia Pustaka Utama.

Wong, M. B. (2009) Plastic Analysis and Design of Steel Structures, ButterworthHeinemann, London. doi: 10.1016/B978-0-7506-8298-5.X0001-4. 